\title{
Injection of mineral dust into the free troposphere during fire events observed with polarization lidar at Limassol, Cyprus
}

\author{
A. Nisantzi ${ }^{1}$, R. E. Mamouri ${ }^{1}$, A. Ansmann ${ }^{2}$, and D. Hadjimitsis ${ }^{1}$ \\ ${ }^{1}$ Cyprus University of Technology, Dep. of Civil Engineering and Geomatics, Limassol, Cyprus \\ ${ }^{2}$ Leibniz Institute for Tropospheric Research, Leipzig, Germany
}

Correspondence to: A. Nisantzi (argyro.nisantzi@cut.ac.cy)

Received: 16 May 2014 - Published in Atmos. Chem. Phys. Discuss.: 27 June 2014

Revised: 25 September 2014 - Accepted: 29 September 2014 - Published: 19 November 2014

\begin{abstract}
Four-year observations (2010-2014) with EARLINET polarization lidar and AERONET sun/sky photometer at Limassol $\left(34.7^{\circ} \mathrm{N}, 33^{\circ} \mathrm{E}\right)$, Cyprus, were used to study the soil dust content in lofted fire smoke plumes advected from Turkey. This first systematic attempt to characterize less than 3-day-old smoke plumes in terms of particle linear depolarization ratio (PDR), measured with lidar, contributes to the more general effort to properly describe the life cycle of free-tropospheric smoke-dust mixtures from the emission event to phases of long-range transport ( $>4$ days after emission). We found significant PDR differences with values from 9 to $18 \%$ in lofted aerosol layers when Turkish fires contributed to the aerosol burden and of 3-13\% when Turkish fires were absent. High Ångström exponents of 1.4-2.2 during all these events with lofted smoke layers, occurring between 1 and $3 \mathrm{~km}$ height, suggest the absence of a pronounced particle coarse mode. When plotted vs. travel time (spatial distance between Limassol and last fire area), PDR decreased strongly from initial values around 16-18\% (1 day travel) to 4-8\% after 4 days of travel caused by deposition processes. This behavior was found to be in close agreement with findings described in the literature. Computation of particle extinction coefficient and mass concentrations, derived from the lidar observations, separately for fine-mode dust, coarse-mode dust, and non-dust aerosol components show extinction-related dust fractions on the order of $10 \%$ (for $\mathrm{PDR}=4 \%$, travel times $>4$ days $)$ and $50 \%(\mathrm{PDR}=15 \%$, 1 day travel time) and respective mass-related dust fractions of $25 \%(\mathrm{PDR}=4 \%)$ to $80 \%(\mathrm{PDR}=15 \%)$. Biomass burning should therefore be considered as another source of free tropospheric soil dust.
\end{abstract}

\section{Introduction}

Biomass burning smoke affects air quality, visibility, and climate directly and indirectly. Hot fire smoke plumes easily reach the free troposphere (FT) (Amiridis et al., 2010) and can be transported from continent to continent within 1 week (Fiebig et al., 2002; Mattis et al., 2003; Murayama et al., 2004; Müller et al., 2005; Petzold et al., 2007; Ansmann et al., 2009; Baars et al., 2011) and around the globe within 2-3 weeks (Damoah et al., 2004). These plumes partly reach the upper troposphere (Mattis et al., 2008; Dahlkötter et al., 2014). Fire smoke must be regarded as an important source of the free-tropospheric background aerosol. It is well known that strong winds inside the combustion zones can raise considerable amounts of soil particles into the atmosphere (Palmer, 1981; Gaudichet et al., 1995; Maenhaut et al., 1996; Clements et al., 2008; Chalbot et al., 2013). Fires around the world may thus also be significant sources of FT dust particles which influence climate directly and indirectly as favorable cloud condensation and ice nuclei (Pratt et al., 2011; McCluskey et al., 2014).

For an adequate consideration of fire-related dust and smoke particles in atmospheric models, it is desirable to improve our knowledge about the life cycle of fire smoke plumes from the emission and regional transport during the first several days up to the long-range and intercontinental transport and corresponding travel times of 7-20 days after emission. From ground-based in situ aerosol field studies close to fires, we know that soil dust particles form a pronounced coarse mode in the beginning. According to Gaudichet et al. (1995) and Maenhaut et al. (1996), 75-99\% of the coarse particles were found to be dust in smoke of flaming African savanna fires. 
In contrast, airborne in situ observations of fire smoke plumes originating from North American forest fires indicate that super micrometer particles (coarse-mode particles) are almost absent in aged smoke plumes after long-range transport of 4-6 days. However, the accumulation mode of the particles in these plumes is enhanced and shifted to mode diameters of 200-400 nm compared to smoke-free background aerosol observations (Fiebig et al., 2002; Petzold et al., 2007; Dahlkötter et al., 2014). Particle linear depolarization ratios of 6-8\% and sometimes up to $15 \%$ in North American fire smoke after long range transport observed with polarization lidars (Fiebig et al., 2002; Murayama et al., 2004) point to fine-mode dust particles contributions of about $5-40 \%$ to the observed particle optical properties of the aged smoke layers.

Polarization lidar observations of the particle linear depolarization ratio allow us to separate fine-mode and coarsemode dust and to distinguish dust from non-dust aerosol contributions to the measured particle mass concentration, optical depth, and extinction coefficients (Tesche et al., 2009; Mamouri and Ansmann, 2014). Only irregularly shaped particles such as mineral dust particles (soil, road, and desert dust) cause strong depolarization of emitted linearly polarized laser light, whereas spherical or almost spherical particles such as anthropogenic haze, biomass-burning smoke, and marine particles do not produce strong depolarization of backscattered light (Tesche et al., 2011; Groß et al., 2011, 2013; Ansmann et al., 2011, 2012). Our dust detection method may be biased by light-depolarizing ash particles. However, these large particles are assumed to fall out quickly, within 1 day after injection. The observations, discussed in Sect. 3, at least do not indicate the presence of large particles during fire smoke events.

To better characterize free-tropospheric fire smoke plumes and mixtures of dust and smoke as well as changes in the microphysical and optical properties of these mixed aerosol layers with travel time, lidar measurements of the particle linear depolarization ratio in fire smoke plumes especially during the first 3 days after emission are required. A first systematic attempt to fill this gap is undertaken in this paper. We analyzed polarization lidar observations performed at the EARLINET site of Limassol, Cyprus, from April 2010 to February 2014. These results are presented in Sect. 3. In our study, we concentrated on air masses advected from Turkey and regions further north of the Black Sea area during the main burning season (summer half year). We separated cases with strong impact of smoke events (occurring over Turkey during 1-3 days before arrival at Limassol) from observations with more background-like aerosol signatures (not influenced by Turkish fire smoke). We found significant differences in the depolarization characteristics of the backscattered laser light. The particle linear depolarization ratio (the definition is given in the Sect. 2) was typically 10-15\% when Turkish fires contributed to the aerosol burden in the free troposphere and considerably lower with values of $3-8 \%$ when fires over Turkey were absent while the air masses crossed this country.
AERONET photometer observations showed high Ångström exponents (mainly from 1.4 to 2.0) during all these events with lofted smoke layers suggesting the absence of a pronounced particle coarse mode. Depolarization ratios of 10 $15 \%$ then point to fine-mode dust contributions on the order of $50 \%$ to the observed optical particle properties as will be discussed in Sect. 3.

The paper is organized as follows: in Sect. 2, the lidar and photometer instruments as well as the lidar data analysis are briefly described. Section 3 presents observational case studies and statistical results of our aerosol observations, and integrates the findings into the broader context of published lidar observations of aged smoke-dust plumes. A summary and concluding remarks are given in Sect. 4.

\section{Instrumentation and data analysis tools}

\subsection{EARLINET polarization lidar}

The lidar station of the Cyprus University of Technology (CUT) at Limassol $\left(34.7^{\circ} \mathrm{N}, 33^{\circ} \mathrm{E} ; 50 \mathrm{~m}\right.$ a.s.1.) (Mamouri et al., 2013) is member of the European Aerosol Research Lidar Network (EARLINET) (Pappalardo et al., 2014). The site is located about $150 \mathrm{~km}$ south of Turkey and $250 \mathrm{~km}$ west of Syria. The lidar transmits linearly polarized laser pulses at $532 \mathrm{~nm}$ and detects the parallel- and cross-polarized signal components at this wavelength. From the calibrated ratio of the cross-to-parallel-polarized lidar signals, the volume linear depolarization ratio can directly be determined (Freudenthaler et al., 2009). Calibration of the polarization channels is performed by rotating the box with the polarization sensitive channels following the methodology of Freudenthaler et al. (2009). The transmission properties of the receiver (for parallel and perpendicularly polarized light) required for an accurate determination of the particle linear depolarization ratio are known from measurements. The uncertainty in the volume linear depolarization ratio is $\leq 5 \%$. In the following, the linear depolarization ratio is simply denoted as depolarization ratio.

The full overlap of the laser beam with the receiver field of view of the $20 \mathrm{~cm}$ Cassegrain telescope is obtained at heights around $300 \mathrm{~m}$ a.s.l. (Mamouri et al., 2013). The measured volume depolarization ratio is reliable to about $50 \mathrm{~m}$ above ground. Overlap effects widely cancel out here because the depolarization ratios are calculated from signal ratios. However, for this study we only analyzed data for heights above $300 \mathrm{~m}$ and set the depolarization ratio below $300 \mathrm{~m}$ to a height-independent value (see discussion in Sect. 3).

Our study presented in Sect. 3 is based on height profiles of the particle backscatter coefficient and the particle depolarization ratio at $532 \mathrm{~nm}$. The determination of the particle backscatter coefficient is described in detail by Mamouri et al. (2013). The particle depolarization ratio is computed from the volume depolarization ratio by means 


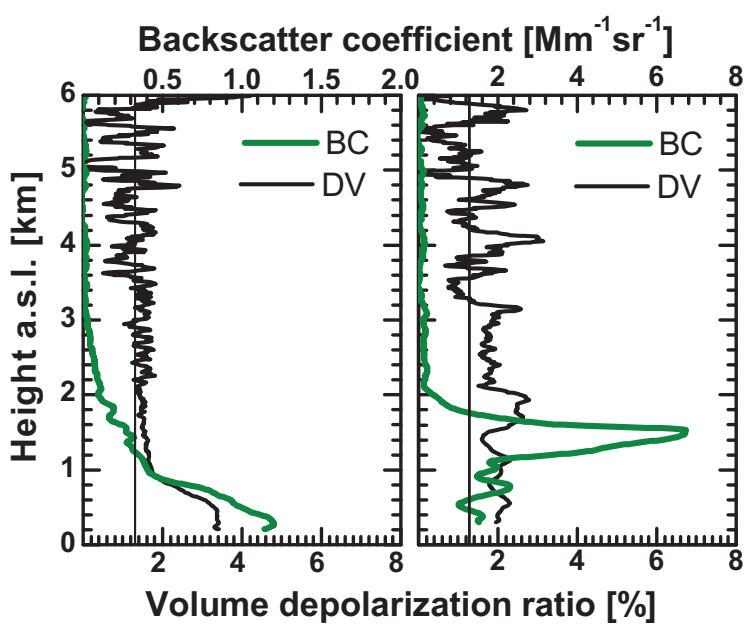

Figure 1. $532 \mathrm{~nm}$ particle backscatter coefficient (BC, green) and volume linear depolarization ratio (DV, black) measured on 2 days with almost particle-free conditions above $2-3 \mathrm{~km}$ height. The vertical lines indicate DV $=1.3 \%$. This value was used in the data analysis as Rayleigh depolarization ratio (clear air DV).

of the determined particle backscatter coefficient (Freudenthaler et al., 2009). Uncertainties in the retrieval products (particle backscatter coefficient, particle depolarization ratio) are discussed by Mamouri et al. (2013) and are typically on the order of $\leq 10 \%$.

In the retrieval of the particle depolarization ratio, the Rayleigh depolarization ratio (i.e., the depolarization ratio for particle-free air) must be known. The Rayleigh depolarization ratio is estimated from the volume depolarization ratio during clear days in aerosol-free air. Figure 1 presents two examples. Although the shown volume linear depolarization ratio is noisy at heights above the main aerosol layers reaching up to about $2-3 \mathrm{~km}$ height, one can see that the volume depolarization ratio assumes values around $1 \%$ at heights above $4 \mathrm{~km}$. The volume depolarization is equal to the depolarization ratio for pure Rayleigh backscattering (in cases with negligible particle backscattering). In the data analysis, discussed in Sect. 3, we used a fixed Rayleigh depolarization ratio of $1.3 \%$ for all measurement cases. The uncertainty introduced by a wrong Rayleigh value of $\pm 1 \%$ is on the order of $1-2 \%$ in the particle depolarization ratio.

Figure 1 also shows that the volume depolarization ratio in pronounced aerosol layers can be as low as about $2 \%$ in cases with westerly winds (right panel) when maritime particles and aged anthropogenic haze from western, southern, and central Europe dominate the aerosol conditions over the eastern Mediterranean. Values around 2-3\% are typical for maritime particles (Groß et al., 2011, 2013). As mentioned above, road and soil dust emitted around Limassol and even dried marine particles (dry sea salt) may contribute to the measured light depolarization, but these effects are assumed to be small and mainly confined to the boundary layer (lowest $400 \mathrm{~m}$ )

Recently, a new polarization-lidar-based method was introduced by Mamouri and Ansmann (2014) that allows us to separate spherical (marine and continental fine-mode and marine coarse-mode particles), fine-mode dust particles causing particle depolarization ratios around 16\% (Sakai et al., 2010), and coarse-mode dust particles causing particle depolarization ratios around 39\% (Sakai et al., 2010). The fine mode includes all particles with radii $<500 \mathrm{~nm}$. We used the new technique to estimate the contribution of fine-mode and coarse-mode dust to the mass concentrations and particle extinction coefficients in the detected smoke-dust plumes in Sect. 3.

As described by Mamouri and Ansmann (2014), a twostep approach is applied to the measured $532 \mathrm{~nm}$ backscattercoefficient profiles. In our study, we explicitly assume that free-tropospheric spherical particles cause depolarization ratios of $1 \%$, that the fine-mode aerosol mixture of smoke and dust causes a particle depolarization ratio of $8 \%$ (assuming a mixture of roughly $50 \%$ smoke and $50 \%$ dust), and that, as mentioned, the coarse-mode dust particles cause a depolarization ratio of $39 \%$. According to the error discussions by Mamouri et al. (2013) and Mamouri and Ansmann (2014), the overall uncertainty in the separation of the backscatter and extinction coefficients for the different aerosol types is on the order of $20-40 \%$, and the uncertainty in the retrieved mass concentration profiles is about $50 \%$.

\subsection{AERONET sun/sky photometer}

The lidar is collocated with a sun/sky photometer of the Aerosol Robotic Network (AERONET, CUT-TEPAK site, Limassol, Cyprus; http://aeronet.gsfc.nasa.gov) (Holben et al., 1998). The CUT AERONET photometer measures the aerosol optical thickness (AOT) at eight wavelengths from 339 to $1638 \mathrm{~nm}$. From the spectral AOT distribution, the Ångström exponent, AE (Ångström, 1964), and the finemode fraction FMF (fraction of fine-mode AOT to total AOT) (O'Neill et al., 2003) are retrieved. AOT errors are on the order of 0.01-0.02 in the absence of unfiltered cloud contamination (Chew et al., 2012).

\subsection{Combined lidar/photometer data analysis}

Mamouri et al. (2013) provide a detailed description of the lidar data analysis to obtain height profiles of particle backscatter and extinction coefficients at $532 \mathrm{~nm}$, which are in good agreement with the column-integrated photometer observations of AOT. In this approach, the particle depolarization ratio is used to distinguish dust and non-dust contributions to the particle optical properties. Besides height profiles of the particle optical properties, essential products are the derived extinction-to-backscatter ratios (lidar ratios) for the entire tropospheric column $S_{\mathrm{col}}$, for the free troposphere 


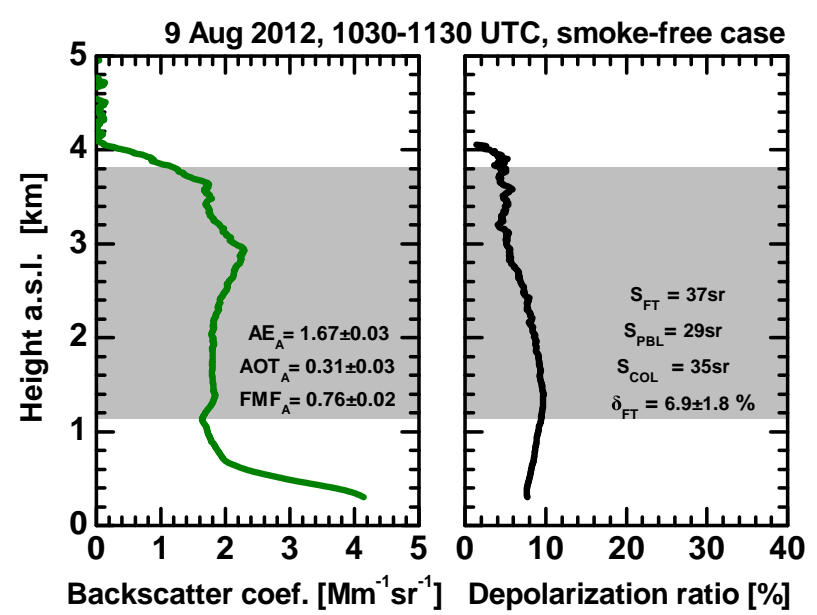

Figure 2. $532 \mathrm{~nm}$ particle backscatter coefficient (left, green) and particle linear depolarization ratio (right, black) in the free troposphere during northerly airflow. No fires occurred over Turkey (smoke-free case). The grey-shaded area indicates the identified lofted aerosol layer. $\mathrm{AE}_{\mathrm{A}}, \mathrm{AOT}_{\mathrm{A}}$, and $\mathrm{FMF}_{\mathrm{A}}$ in the left panel denote Ångström exponent, aerosol particle optical thickness, and fine-mode fraction derived from AERONET photometer observations (for the total tropospheric column). Retrieved lidar ratios $S_{\mathrm{FT}}$ for the free troposphere and $S_{\mathrm{COL}}$ for the total column obtained after Mamouri et al. (2013) are given in the right panel. The boundarylayer lidar ratio $S_{\mathrm{PBL}}$ (for the lowest $400 \mathrm{~m}$ ) is required as input in this retrieval. In addition, the mean particle depolarization ratio $\delta_{\mathrm{FT}}$ for the grey-shaded lofted aerosol layer is given together with the standard deviation.

$S_{\mathrm{FT}}$, and lidar ratios for dust $S_{\mathrm{FT}, \mathrm{D}}$ in the free troposphere. Climatological values (obtained from the long-term observations at Limassol) for the lidar ratio $S_{\mathrm{PBL}}$ of $20-35 \mathrm{sr}$ in the planetary boundary layer (PBL), i.e., for the lowermost $300-400 \mathrm{~m}$ of the tropospheric column, where the overlap of the laser beam with the receiver field of view is incomplete, and for the non-dust free-tropospheric lidar ratio $S_{\mathrm{FT}, \mathrm{S}}$ of 40 $60 \mathrm{sr}$ are required in this retrieval as assumed input. Index $\mathrm{S}$ denotes fine-mode spherical particles in the free troposphere such as fire smoke and anthropogenic haze particles.

\subsection{HYSPLIT backward trajectories}

In order to investigate the influence of fire activities on the observed optical properties of the lofted aerosol plumes crossing Cyprus, we studied the air mass transport by means of backward trajectory analysis. The calculations were performed with the HYSPLIT (HYbrid Single-Particle Lagrangian Integrated Trajectory) Model. Access is provided via the NOAA ARL READY website (http://www.arl. noaa.gov/HYSPLIT.php). HYSPLIT is described in detail in Draxler and Hess $(1997,1998)$ and Draxler (1999).

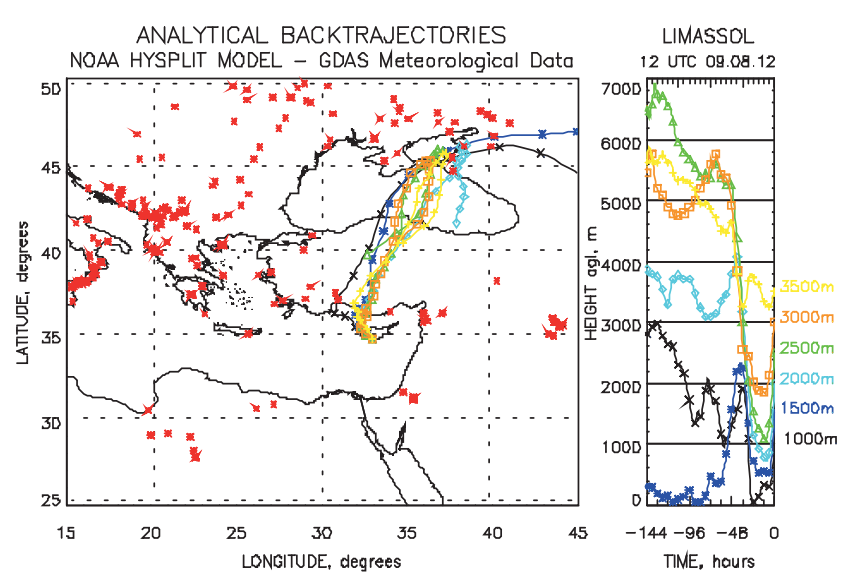

Figure 3. Six-day HYSPLIT backward trajectories arriving at Limassol, Cyprus, at different height levels (black, blue, light blue, green, orange, yellow) on 9 August 2012, 12:00 UTC. Red crosses indicate fire events which occurred during the time period from 2 to 9 August 2012 according to MODIS observations.

\subsection{MODIS fire products}

In order to identify the areas where biomass burning aerosols were generated, MODIS (Moderate Resolution Imaging Spectroradiometer) active fire products were used (Flynn et al., 2002; Giglio et al., 2003). MODIS comprises a multispectral sensor with 36 spectral bands and covers the wavelength range from 0.4 to $14.2 \mu \mathrm{m}$. Single fires are detected with $1 \mathrm{~km}$ spatial resolution. MODIS is flown aboard the two NASA Earth Observing System (EOS) satellites Terra and Aqua. Both satellites are polar orbiting. Fires at the $1 \mathrm{~km}$ scale can be measured up to four times per day. The MODIS algorithms (including the fire algorithm) are updated periodically, leading to different versions, which are used to generate a series of collections of the data products. The latest (Collection 5) fire data were used in this study.

We show 7-day fire spots, i.e., all spots detected within a week before the lidar observation. Data from University of Hawaii (http://modis.higp.hawaii.edu/) are taken. MODIS hot spots are provided with a level of confidence. For the retrievals here the confidence level of $80 \%$ was used, so all values with lower confidence values were excluded. The fire events were then combined with 6-day HYSPLIT backward trajectories in order to estimate the presence and age of smoke plumes detected with the EARLINET lidar.

\section{Results}

The focus of our study is the investigation of the potential of open fires (wild fires and controlled biomass burning) to trigger injection of soil dust into the free troposphere. Another goal was to concentrate on young smoke plumes (not older than 1-3 days). Therefore, we only consider measurement 


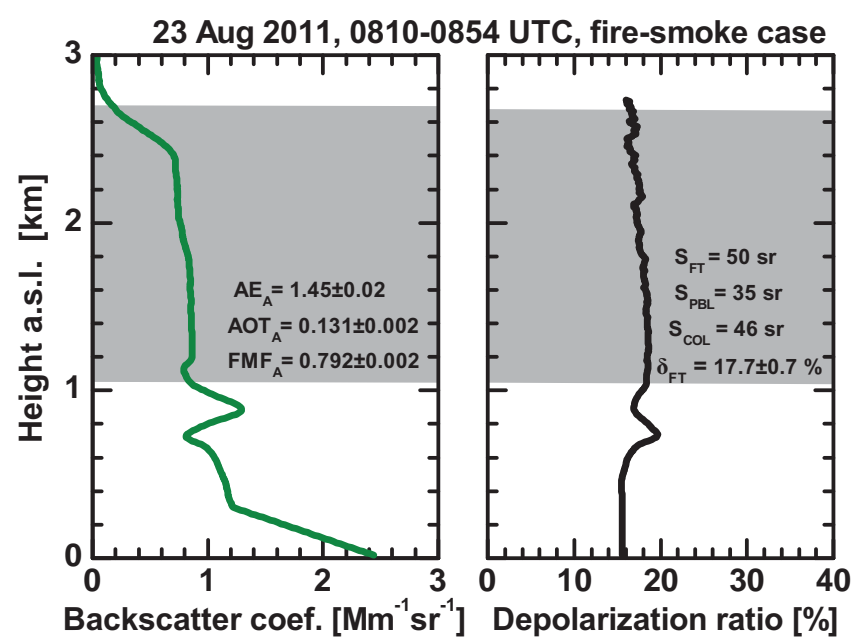

Figure 4. Same as Fig. 2, except for 23 August 2011. A fire smoke case is shown (i.e., air masses crossed fire areas over Turkey before reaching the lidar site). Retrieved values are given as numbers. Input in the lidar ratio retrieval is $S_{\mathrm{PBL}}=35 \mathrm{sr}$.

cases of air mass transport from northerly directions crossing Turkey. We observed 45 respective cases from April 2010 to February 2014. In 24 out of the 45 cases presented here, the backward trajectories together with the MODIS fire maps indicated that the measured lidar profiles were influenced by Turkish fire smoke.

We begin with two case studies. The measurement examples in Figs. 2 and 4 together with Figs. 3 and 5 (HYSPLIT backward trajectories and MODIS fire information) provide a contrasting impression of the differences in the observed particle depolarization ratios when no fires were observed by MODIS over Turkey (Fig. 2) and when several fires over central Turkey influenced the lidar measurements over Limassol significantly (Fig. 4). In the smoke-free case, the particle depolarization ratio was less than $10 \%$ throughout the entire free troposphere from $500 \mathrm{~m}$ to $4 \mathrm{~km}$ height. The aerosol plume was well mixed. The moderately enhanced particle depolarization ratios (compared to low values of $1-3 \%$ for haze pollution and fine-mode smoke) may indicate the influence of soil dust from arid regions, from remote deserts, and dust injected during fires at times 3-7 days before the arrival of the air masses at Limassol from areas north of the Black Sea.

The Ångström exponent of $\mathrm{AE}_{\mathrm{A}}=1.67$ and fine-mode fraction $\mathrm{FMF}_{\mathrm{A}}=0.76$ from the AERONET observations indicate the dominance of fine-mode particles throughout the entire troposphere. The particle optical depth of $\mathrm{AOT}_{\mathrm{A}}=$ 0.31 and extinction-to-backscatter ratios $S_{\mathrm{FT}}$ of $37 \mathrm{sr}$ in the free troposphere indicate a high aerosol load of a mixture of aged, less absorbing anthropogenic haze, fire smoke, and background aerosols from rural areas.

Figure 4 represents a measurement case with strong influence of Turkish fire smoke (see also Fig. 5). Again, a wellmixed lofted layer of smoke and dust was found above $1 \mathrm{~km}$

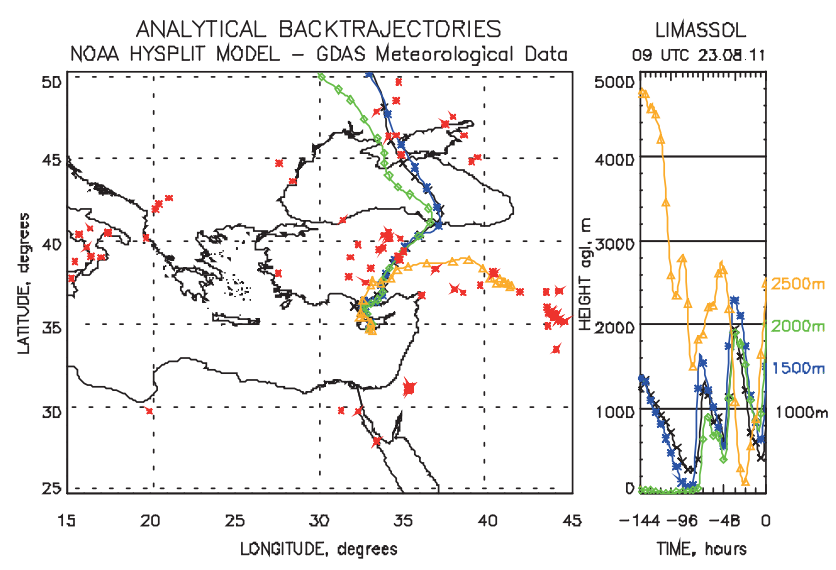

Figure 5. Same as Fig. 3, except for 23 August 2011. Red crosses indicate fire events which occurred during the time period from 16 to 23 August 2011.

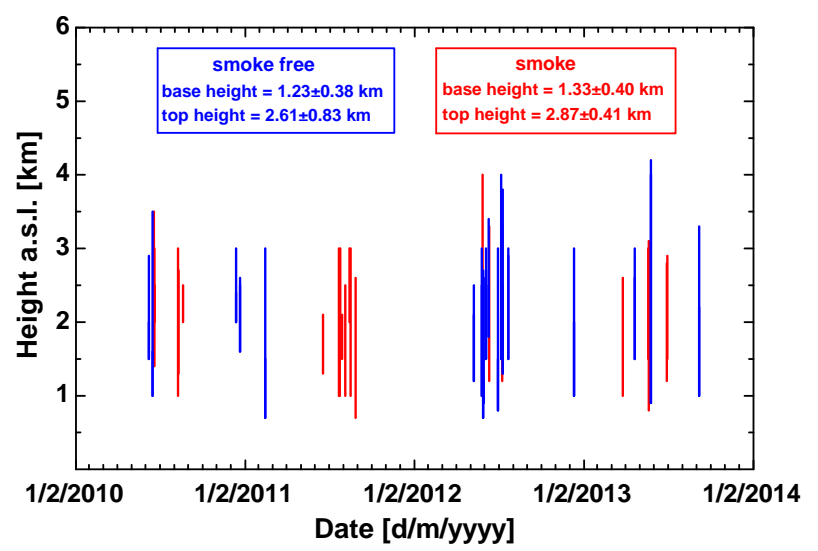

Figure 6. Lofted free-tropospheric aerosol layers (shown as vertical lines from bottom to top) observed during northerly air flows between April 2010 and February 2014. In the case of the blue vertical lines (21 smoke-free cases) no fire events over Turkey occurred and influenced the lidar measurements. In the case of the red layers (24 fire smoke cases), the air masses crossed fire areas over Turkey before arriving at the lidar site at Limassol. The average bottom and top heights (plus one standard deviation) of all detected layers, separately for smoke and smoke-free cases, are given in addition.

height. The layer-mean particle depolarization ratio of almost $18 \%$ is the highest depolarization value we observed during the 4 years of lidar measurements of northerly air flows. However most of the dust seems to be again fine-mode dust because the Angström exponent of $\mathrm{AE}_{\mathrm{A}}=1.45$ and the finemode fraction $\mathrm{FMF}_{\mathrm{A}}=0.792$ are again comparably high. Lidar ratios $S_{\mathrm{FT}}$ in the free troposphere of around $50 \mathrm{sr}$ point to a mixture of moderately absorbing smoke particles $(60 \mathrm{sr})$ and less absorbing, non-spherical dust particles (35-45 sr).

Figure 6 provides an overview of the geometrical properties of 45 aerosol layers in the lower free troposphere observed during the 4-year period from April 2010 to Febru- 


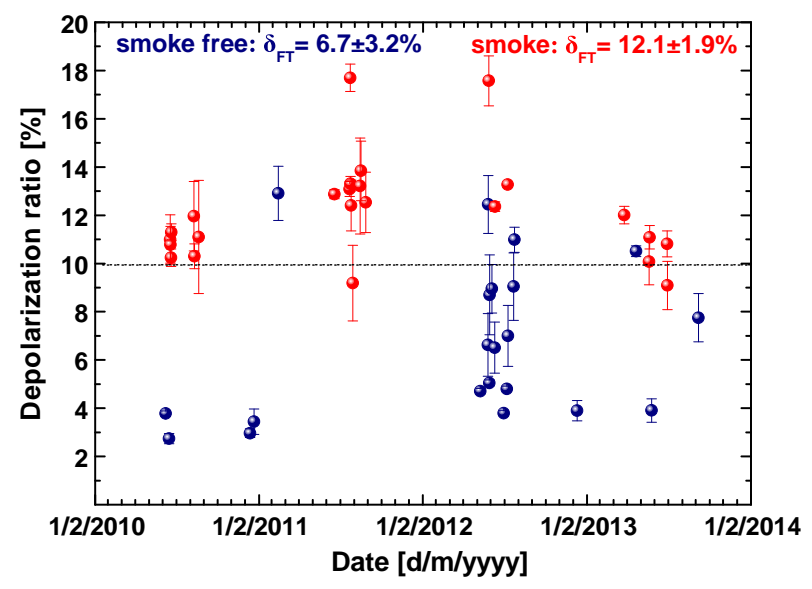

Figure 7. Layer-mean particle linear depolarization ratio of all 21 blue layers (no influence of Turkish smoke) and 24 red layers (influenced by fires in Turkey) that are given in Fig. 6. Vertical bars indicate the atmospheric variability (standard deviation) of the depolarization ratio within the detected layers. Most fire-smoke cases show enhanced particle depolarization ratios ( $>10 \%$, red circles). The average layer-mean depolarization ratios of all 21 blue and 24 red layers and corresponding standard deviations are given as numbers.

ary 2014. Most layers were found between 1 and $3 \mathrm{~km}$ height with layer centers around $1.9-2 \mathrm{~km}$ height. On average, the smoke layers showed a vertical extent of $1.4-1.5 \mathrm{~km}$. Based on spaceborne CALIPSO lidar data, Amiridis et al. (2010) found most top heights (injection heights) of smoke layers between 2 and $4 \mathrm{~km}$ for the summer months of 2006-2008. The average top height was $3.1 \mathrm{~km}$. This is in good agreement with our observations (mean top height at about $2.9 \mathrm{~km}$ height).

Figure 7 presents the time series of derived layer-mean particle depolarization ratios. Most values were $>10 \%$ when the air masses crossed fire areas over Turkey. For cases free of Turkish smoke we observed values from 3 to $13 \%$. Depolarization ratios below $<4 \%$ may indicate dustfree conditions in the free troposphere. The variability in the depolarization ratio may reflect the influence of numerous dust sources around the eastern Mediterranean. A seasonal cycle in the depolarization ratio time series is not visible because most northerly flows occur during the summer season. In winter the release of soil dust may be generally reduced by enhanced precipitation (increased wash out), wet soils (prohibit dust emission), and the presence of snow covers (in the Turkish mountains and further north and east).

An overview of the optical properties (range of values) of all layers for northerly air mass advection is presented in Fig. 8. Layers with comparably fresh fire smoke from Turkey (red symbols, depolarization values from 9 to $18 \%$ ) showed low backscatter coefficients around $1 \pm 0.5 \mathrm{Mm}^{-1} \mathrm{sr}^{-1}$. Multiplication with a typical lidar ratio of $40-50$ sr yields smokedust layer particle extinction coefficients on the order of 25

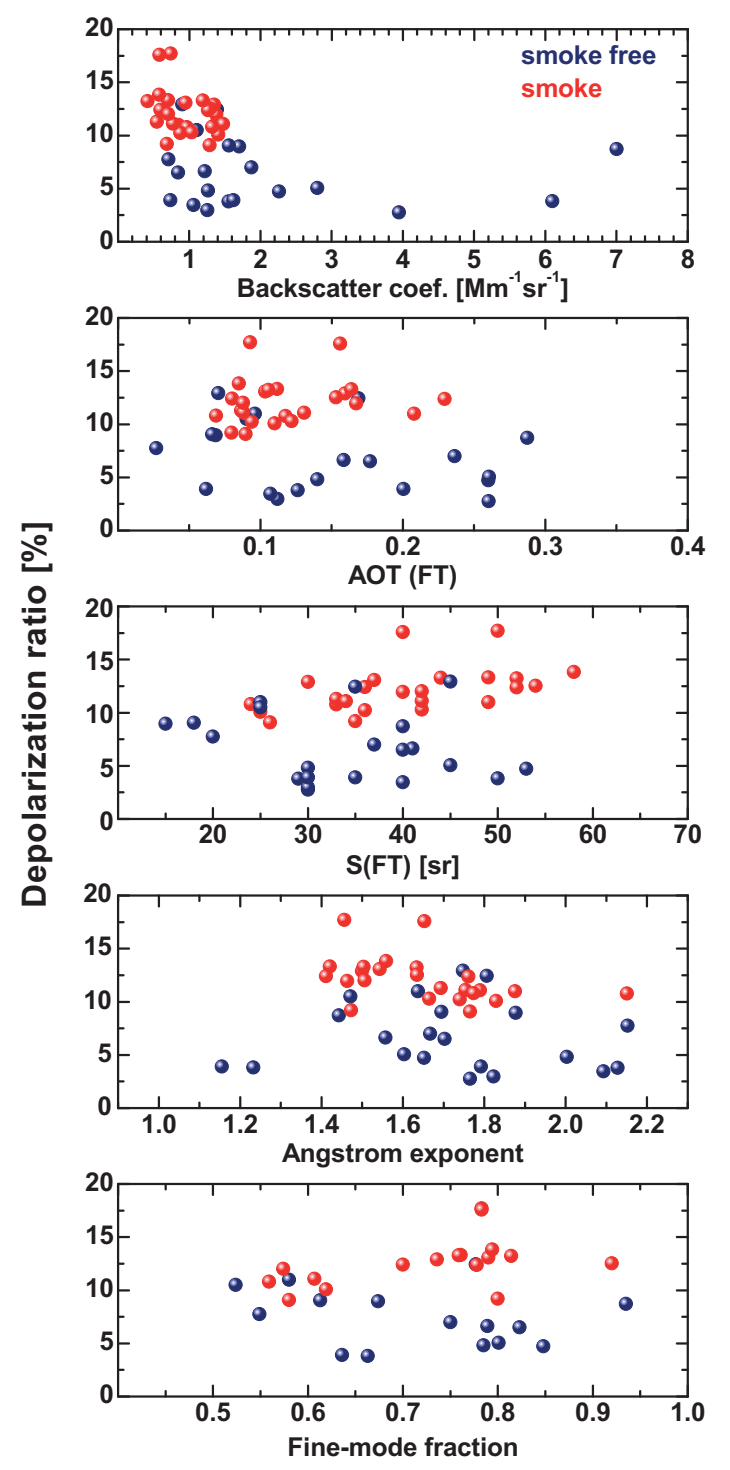

Figure 8. Range of observed values of the particle backscatter coefficient (mean value of the lofted aerosol layers), free-tropospheric aerosol particle optical thickness AOT(FT), lidar ratio $S(\mathrm{FT})$ in the lofted aerosol layers, Angström exponent for the total vertical column, and fine-mode fraction (regarding the total tropospheric $500 \mathrm{~nm}$ AOT) for the Turkish fire-smoke cases (red circles) and the cases without smoke from Turkey (blue circles). All values (circles) are given as a function of layer-mean particle linear depolarization ratio to better distinguish between fire-smoke and smoke-free cases.

$75 \mathrm{Mm}^{-1}$. For the smoke-free cases, several large backscatter coefficients $>3 \mathrm{Mm}^{-1} \mathrm{sr}^{-1}$ were observed which may indicate the influence of marine particles. Even during northerly airflows, sea breeze effects on the south coast of Turkey and the north coast of Cyprus (including mountain-induced circulation effects over Cyprus) and corresponding injection of marine particles into the lowermost $1-2 \mathrm{~km}$ of the atmosphere can never be completely excluded when interpret- 


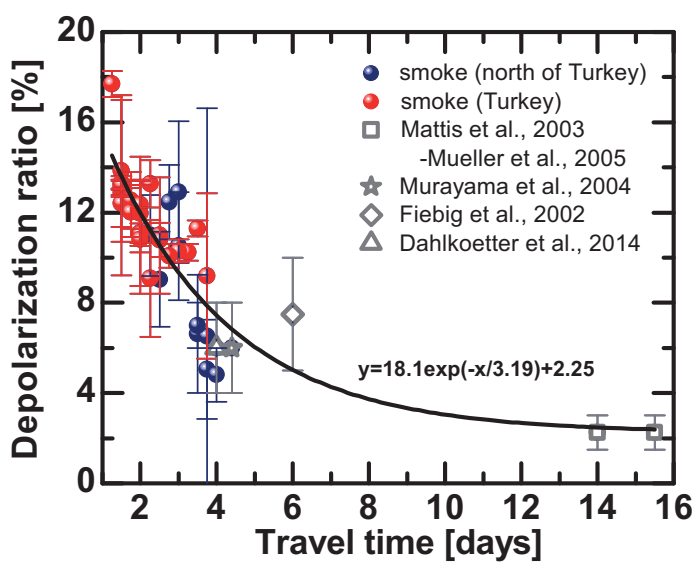

Figure 9. Decrease of the layer-mean particle linear depolarization ratio of smoke-influenced aerosol layers with increasing travel time, defined as the temporal distance between Limassol and the last fire area which the observed air masses crossed before arriving at Limassol. Ten of the 21 blue circles (cases without Turkish smoke) were influenced by smoke generated in areas north of the Black Sea. The exponential fit indicates a 1/e decay time (dust decrease) of 4 days. Grey symbols show observations as published in the given literature. Vertical bars show the range of observed depolarization ratios (literature values) or show the standard deviation of the values determined within the individual layers (red and blue values).

ing free-tropospheric lidar observations at Limassol. But as shown, these events are rare.

The $532 \mathrm{~nm}$ AOT for smoke-dust plumes was found to be in the range from 0.05 to 0.25 . According to Mattis et al. (2003), Murayama et al. (2004) and Müller et al. (2005), AOT decreases to values of 0.02-0.05 after long-range transport of 4-15 days. Lidar ratios of the smoke-dust layers range from 25 to $60 \mathrm{sr}$, and indicate at all less absorbing aerosol layers (red symbols in Fig. 8, third panel). Low values of $<25 \mathrm{sr}$ can be caused by rural background aerosols (Hänel et al., 2012) as well as by marine particles (Groß et al., 2011). Ångström exponents for the entire tropospheric column from 1.4 to 2.2 indicate that the smoke-dust plumes mainly consisted of fine-mode particles (Aitken mode, accumulation mode). Coarse-mode dust particles were obviously removed quickly and efficiently. Similarly, fine-mode fractions for the entire tropospheric column (including the marine boundary layer and thus coarse marine particles) of 0.55-0.95 indicate the dominance of fine-mode particles in the lofted smoke-dust aerosol mixtures. Markham et al. (1997), O'Neill et al. (2002) and Müller et al. (2007) also reported Ångström exponents $>1.4$ during fire smoke events (within the first 2-3 days after emission).

Figure 9 shows the dependence of the layer-mean particle depolarization ratio on travel time (i.e., the spatial distance between Limassol and the last fire area upwind of the lidar site). The travel time is calculated from the HYSPLIT backward trajectories for the smoke layer centers. As can be seen, the depolarization ratio drops from $14-18 \%$ (day 1) to about $5 \%$ (day 4). Several literature values are shown in addition and corroborate the observed trend. Our fire smoke data ( $<4$-day-old smoke) together with literature values provide, for the first time, an impression of how fast the depolarization ratio and thus the dust fraction decreases with time. The exponential fit curve in Figure 9 indicates a 1/e decay time of 4 days. Our data clearly fill an observational gap and contribute to the effort to properly describe the life cycle of free-tropospheric smoke-dust mixtures from the emission event to phases of long-range transport.

Assuming mean wind speeds of $5-10 \mathrm{~m} \mathrm{~s}^{-1}$ in the lower free troposphere over Turkey and areas north of Turkey, the air masses traveled $450-900 \mathrm{~km}$ per day. At greater heights wind speeds of $>15 \mathrm{~m} \mathrm{~s}^{-1}$ are typical so that smoke plumes may travel $>1350 \mathrm{~km}$ per day (as is the case for the shown literature cases in Fig. 9).

The observed scatter in the data in Fig. 9 can be related to many reasons. First of all, there are uncertainties in the assignment of the fire events (after MODIS) to our lidar observations by using uncertain backward trajectories and fire information integrated over 7 days. Second, the soil characteristics and fire-induced dust injection efficiency may differ significantly from site to site, even for favorable arid regions such as Turkey. The literature values in Fig. 9 include Siberian as well North American biomass-burning smoke plumes. Third, free-tropospheric meteorological conditions can vary strongly along the transport path ways and thus also the aerosol mixing, diffusion, deposition, and particle growth processes. It was observed that (spherical) smoke particles increase their sizes during long-range transport because of gas-to-particle conversion and water uptake (Müller et al., 2007). The increasing backscatter coefficient for spherical particles then leads to a decrease of the observed particle depolarization ratio. Fourth, flaming fires as well as smoldering fires can occur. Flaming fires may be more efficient regarding the mobilization of surface soil dust. Fifth, some plumes observed with lidar may have been influenced by many (flaming and smoldering) fires, others by just one (flaming or smoldering) burning event. Sixth, it can also not be excluded that large, irregularly shaped fire particles affected the lidar depolarization measurement, especially in very fresh smoke plumes. Finally, the nearby deserts in the Middle East and North Africa may have also contributed to the free tropospheric dust load.

In Figs. 10 and 11 two cases with high depolarization ratio in the smoke plume (PDR $=14 \%$, travel time $<2$ days) and low depolarization ratio (PDR $=4.6 \%$, travel time of 4 days) are shown to quantify the range of dust contributions to the observed optical properties in the free tropospheric layer. The profiles of particle extinction coefficient were computed from the retrieved backscatter coefficients by using a lidar ratio $S_{\mathrm{FT}, \mathrm{S}}$ of $45 \mathrm{sr}$ for fine-mode spherical particles, and the retrieved dust lidar ratios $S_{\mathrm{FT}, \mathrm{D}}$ were close to $30 \mathrm{sr}$ in these specific two cases. As mentioned in Sect. 2, the retrieval is 


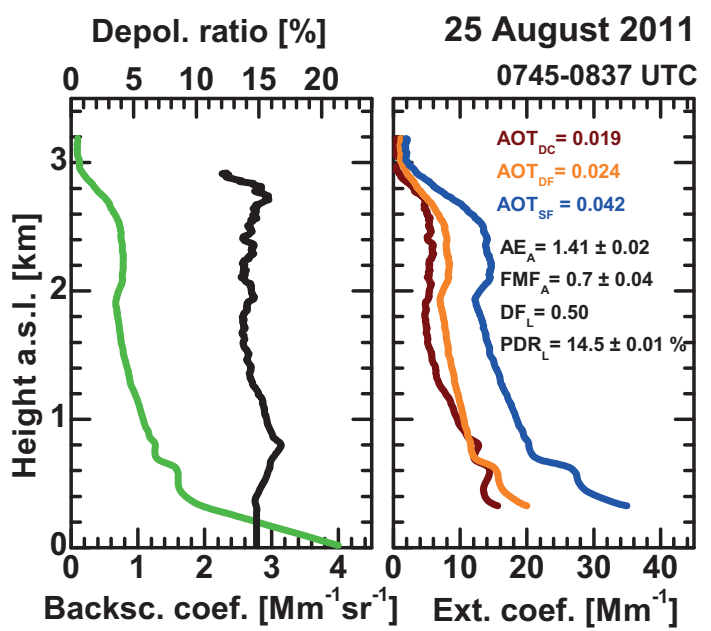

Figure 10. $532 \mathrm{~nm}$ particle backscatter coefficient (green profile, left panel), particle linear depolarization ratio (black profile, left panel), and lidar-derived particle extinction coefficients (right panel) for spherical fine-mode particles (blue profile, index SF), fine-mode dust particles (orange profile, index DF), and coarsemode dust particles (dark red profile, index DC). The extinction coefficient profiles are obtained by using the method of Mamouri and Ansmann (2014). The respective free tropospheric AOTs (above 300-400 m height), the AERONET-derived Angström exponent $\mathrm{AE}_{\mathrm{A}}$ and fine-mode fraction $\mathrm{FMF}_{\mathrm{A}}$ (for total tropospheric column), and the lidar-derived dust fraction $\mathrm{DF}_{\mathrm{L}}$ (with respect to the free tropospheric $532 \mathrm{~nm}$ AOT) are given as numbers together with the layer-mean depolarization ratio $\mathrm{PDR}_{\mathrm{L}}$ and standard deviations. The measurement was taken on 25 August 2011.

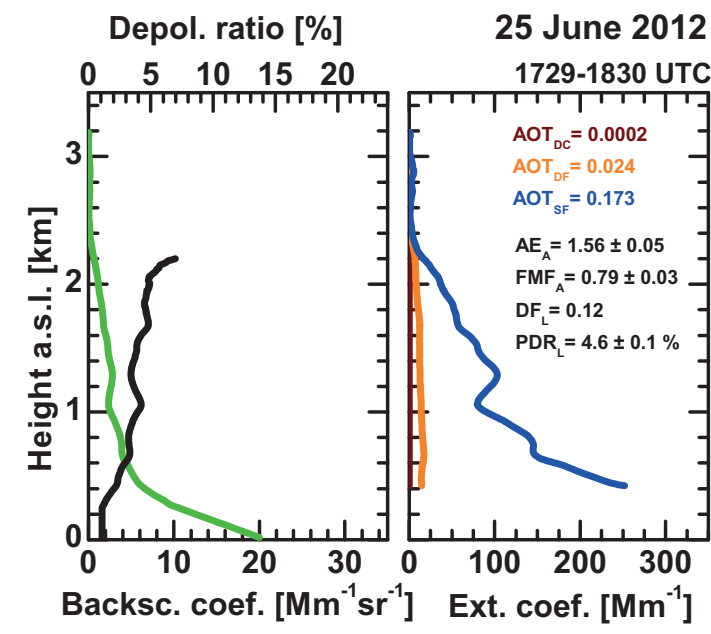

Figure 11. Same as Fig. 10, except for 25 June 2012.

explained in detail by Mamouri et al. (2013) and Mamouri and Ansmann (2014).

On 25 August 2011 (Fig. 10), smoke layer mean extinction coefficients were $18 \mathrm{Mm}^{-1}$ (fine-mode smoke), $10 \mathrm{Mm}^{-1}$ (fine-mode dust), and $8 \mathrm{Mm}^{-1}$ (coarse-mode dust). The dust fraction (DF) of particle extinction and optical depth was thus

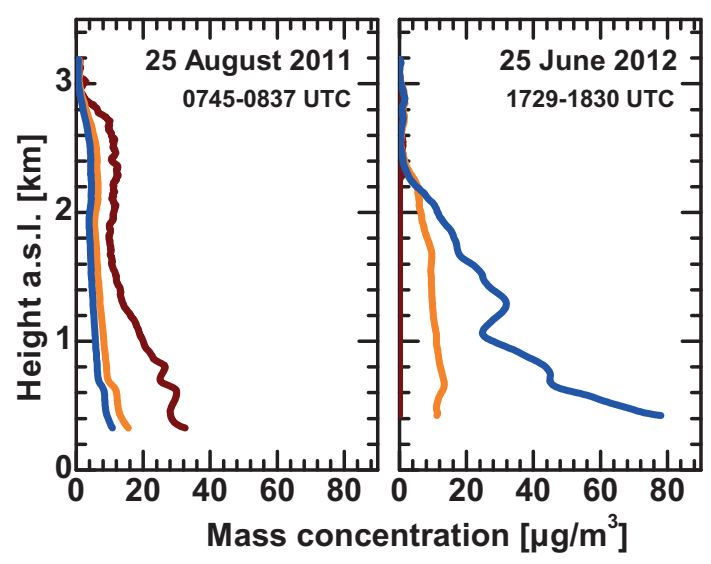

Figure 12. Particle mass concentration profiles (blue: spherical finemode particles, orange: fine-mode dust, dark red: coarse-mode dust) estimated from the particle extinction profiles in Figs. 10 and 11 after the method of Ansmann et al. (2012). Fine-mode and coarsemode dust mass retrieval is described by Mamouri and Ansmann (2014).

$50 \%$. The fine-mode fraction (i.e., the ratio of the sum of the AOTs of fine-mode dust and fine-mode spherical particles to the total AOT (at $500 \mathrm{~nm}$ )) was 0.7 for the total tropospheric column (AERONET) and 0.77 in the FT on the basis of the lidar-derived profiles shown in Fig. 10.

On 25 June 2012 (Fig. 11) the FT aerosol layer was almost smoke free. The mean extinction coefficients in the lofted layer from 400 to $3000 \mathrm{~m}$ were $86.5 \mathrm{Mm}^{-1}$ for spherical particles (probably mainly fine-mode urban haze) and $12.5 \mathrm{Mm}^{-1}$ for fine-mode dust. The dust fraction was in this case $\mathrm{DF}_{\mathrm{L}}=12 \%$. The fine-mode fraction after AERONET was 0.79 , and 1 in the free troposphere according to the lidar extinction profiles in Fig. 11. Ångström exponents of 1.41 and 1.56 indicate the dominance of fine-mode particles in both cases.

In terms of particle mass concentration, the dust fraction in the mixed aerosol plumes is even higher. This is shown in Fig. 12. Mass concentrations were determined from the extinction coefficient profiles after Ansmann et al. (2012) and Mamouri and Ansmann (2014). In this estimation we used particle densities of 2.6 and $1.55 \mathrm{~g} \mathrm{~cm}^{-3}$ for mineral dust particles and non-dust fine-mode particles, respectively. For the required particle volume-to-extinction conversion factors, we applied values of $0.2 \times 10^{-6} \mathrm{~m}, 0.3 \times 10^{-6} \mathrm{~m}$, and $0.8 \times 10^{-6} \mathrm{~m}$ for fine-mode spherical particles, fine dust, and coarse dust, respectively (Mamouri and Ansmann, 2014).

As can be seen in Fig. 12, the layer mean particle mass concentrations were about $5.5 \mu \mathrm{g} \mathrm{m}^{-3}$ (fine-mode spherical smoke particles), $8 \mu \mathrm{g} \mathrm{m}^{-3}$ (fine-mode dust), and $16.5 \mu \mathrm{g} \mathrm{m}^{-3}$ (coarse-mode dust) for the smoke case observed on 25 August 2011. The dust fraction was about $80 \%$ on this day. Even on 25 June 2012 (case with background-level smoke and dust) the dust mass fraction was $25 \%$ for the ob- 
served case with the low PDR $=4.6 \%$. We can conclude that dust mass fractions were on the order of $30-70 \%$ in aged smoke-dust plumes observed over Limassol after travel times of 2-4 days. McCluskey et al. (2014) also reported considerable soil dust mass concentrations of $20-30 \%$ to wildfire particle mass concentrations. Fire smoke aerosol plumes in the free troposphere must be regarded as a non-negligible reservoir for dust and thus for cloud condensation and ice nuclei in the free troposphere.

\section{Conclusions}

Four-year observations (2010-2014) with EARLINET polarization lidar and AERONET sun/sky photometer at Limassol, Cyprus, were used to study the soil dust content in lofted fire smoke plumes advected from Turkey. This first systematic attempt to characterize less than 3-day-old smoke plumes in terms of particle depolarization filled an observational gap and contributes to the more general effort to properly describe the life cycle of free-tropospheric smoke-dust mixtures from the emission event to phases of long-range transport.

We found significant differences in PDR. PDR was 9$18 \%$ in lofted Turkish smoke-dust-haze aerosol layers and considerably lower with values of 3-13\% when Turkish fires were not detected by MODIS. AERONET photometer observations showed high Ångström exponents (1.4-2.2) during all these events with lofted smoke layers suggesting the absence of a pronounced particle coarse mode. The lofted aerosol layers typically occurred between 1 and $3 \mathrm{~km}$ height. When plotted vs. the travel time (defined as the spatial distance between Limassol and last fires area), PDR decreased strongly from initial values around 16-18\% (1 day of travel) to $4-8 \%$ after 4 days of travel, in agreement with the literature. Computation of particle extinction coefficient and mass concentrations, separately for fine-mode dust, coarse-mode dust, and non-dust aerosol components, shows extinctionrelated dust fractions on the order of $10 \%$ (PDR $=4 \%$, after times of $>4$ days) to $50 \%$ (PDR $=15 \%$, after travel times of 1 day) and mass-related dust fractions of $25 \%(P D R=4 \%)$ to $80 \%$ (PDR $=15 \%$ ). Biomass burning in arid regions must obviously be regarded as a significant source of soil dust that contributes to the background aerosol burden of the free troposphere.

Our study must however be regarded as a first step. More efforts of polarization lidar monitoring of fresh and aged smoke-dust plumes are required at very different places around the world to support our findings. The arid regions in the southeastern part of Europe and in the western part of Asia together with the deserts in the Middle East and North Africa may provide rather favorable conditions for dust injection into the atmosphere (free troposphere). Such almost optimum conditions may not be given at higher latitudes in the
Northern Hemisphere as well as in large parts of the Southern Hemisphere.

Acknowledgements. This work was co-funded by the European Regional Development Fund and the Republic of Cyprus through the Research Promotion Foundation (PENEK/0311/05). A. Nisantzi would like to thank CUT's library for the financial support within Cyprus University of Technology Open Access Author Fund. The research leading to these results has also received scientific support from the European Union Seventh Framework Programme (FP7/2011-2015) under grant agreement no. 262254 (ACTRIS project). The authors gratefully acknowledge the NOAA Air Resources Laboratory (ARL) for the provision of the HYSPLIT transport and dispersion model as well for the provision of Global Data Assimilation System (GDAS) data used in this publication. We are also grateful to AERONET for high-quality sun/sky photometer measurements.

Edited by: S. Kazadzis

\section{References}

Amiridis, V., Giannakaki, E., Balis, D. S., Gerasopoulos, E., Pytharoulis, I., Zanis, P., Kazadzis, S., Melas, D., and Zerefos, C.: Smoke injection heights from agricultural burning in Eastern Europe as seen by CALIPSO, Atmos. Chem. Phys., 10, 1156711576, doi:10.5194/acp-10-11567-2010, 2010.

Ångström, A.: The parameters of atmospheric turbidity, Tellus, 16, 64-75, 1964.

Ansmann, A., Baars, H., Tesche, M., Müller, D., Althausen, D., Engelmann, R., Pauliquevis, T., and Artaxo, P.: Dust and smoke transport from Africa to South America: lidar profiling over Cape Verde and the Amazon rainforest, Geophys. Res. Lett., 36, L11802, doi:10.1029/2009GL037923, 2009.

Ansmann, A., Tesche, M., Seifert, P., Groß, S., Freudenthaler, V., Apituley, A., Wilson, K. M., Serikov, I., Linné, H., Heinold, B., Hiebsch, A., Schnell, F., Schmidt, J., Mattis, I., Wandinger, U., and Wiegner, M.: Ash and fine-mode particle mass profiles from EARLINET-AERONET observations over central Europe after the eruptions of the Eyjafjallajökull volcano in 2010, J. Geophys. Res., 116, D00U02, doi:10.1029/2010JD015567, 2011.

Ansmann, A., Seifert, P., Tesche, M., and Wandinger, U.: Profiling of fine and coarse particle mass: case studies of Saharan dust and Eyjafjallajökull/Grimsvötn volcanic plumes, Atmos. Chem. Phys., 12, 9399-9415, doi:10.5194/acp-12-9399-2012, 2012.

Baars, H., Ansmann, A., Althausen, D., Engelmann, R., Artaxo, P., Pauliquevis, T., and Souza, R.: Further evidence for significant smoke transport from Africa to Amazonia, Geophys. Res. Lett., 38, L20802, doi:10.1029/2011GL049200, 2011.

Chalbot, M. C., Nikolich, G., Etyemezian, V., Dubois, D. W., King, J., Shafer, D., Gamboa da Costa, G., Hinton, J. F., and Kavouras, I. G.: Soil humic-like organic compounds in prescribed fire emissions using nuclear magnetic resonance spectroscopy, Environ Pollut., 181, 167-171, doi: 10.1016/j.envpol.2013.06.008, 2013.

Chew, B. N., Campbell, J. R., Reid, J. S., Giles, D. M., Welton, E. J., Salinas, S. V., and Liew, S. C.: Tropical cirrus cloud contami- 
nation in sun photometer data, Atmos. Environ., 45, 6724-6731, doi:10.1016/j.atmosenv.2011.08.017, 2012.

Clements, C. B., Zhong, S., Bian, X., Heilman, W. E., and Byun, D. W.: First observations of turbulence generated by grass fires, J. Geophys. Res., 113, D22102, doi:10.1029/2008JD010014, 2008.

Dahlkötter, F., Gysel, M., Sauer, D., Minikin, A., Baumann, R., Seifert, P., Ansmann, A., Fromm, M., Voigt, C., and Weinzierl, B.: The Pagami Creek smoke plume after long-range transport to the upper troposphere over Europe - aerosol properties and black carbon mixing state, Atmos. Chem. Phys., 14, 6111-6137, doi:10.5194/acp-14-6111-2014, 2014.

Damoah, R., Spichtinger, N., Forster, C., James, P., Mattis, I., Wandinger, U., Beirle, S., Wagner, T., and Stohl, A.: Around the world in 17 days - hemispheric-scale transport of forest fire smoke from Russia in May 2003, Atmos. Chem. Phys., 4, 13111321, doi:10.5194/acp-4-1311-2004, 2004.

Draxler, R. R.: HYSPLIT4 user's guide, NOAA Tech. Memo. ERL ARL-230, NOAA Air Resources Laboratory, Silver Spring, MD, 1999.

Draxler, R. R. and Hess, G. D.: Description of the HYSPLIT 4 modeling system, NOAA Tech. Memo. ERL ARL-224, NOAA Air Resources Laboratory, Silver Spring, MD, 1997.

Draxler, R. R. and Hess, G. D.: An overview of the HYSPLIT 4 modeling system of trajectories, dispersion, and deposition, Aust. Meteorol. Mag., 47, 295-308, 1998.

Fiebig, M., Petzold, A., Wandinger, U., Wendisch, W., Kiemle, C., Stifter, A., Ebert, M., Rother, T., and Leiterer, U.: Method, accuracy, and inferable properties applied to a biomass-burning aerosol and its radiative forcing, J. Geophys. Res., 107, 8130, doi:10.1029/2000JD000192, 2002.

Flynn, L. P., Wright, R., Garbeil, H., Harris, A. J. L., and Pilger, E.: A global thermal alert using MODIS: initial results from 20002001, Advances in Environmental Monitoring and Modeling, 1, 5-36, 2002.

Freudenthaler, V., Esselborn, M., Wiegner, M., Heese, B., Tesche, M., Ansmann, A., Müller, D., Althausen, D., Wirth, M., Fix, A., Ehret, G., Knippertz, P., Toledano, C., Gasteiger, J., Garhammer, M., and Seefeldner, M.: Depolarization ratio profiling at several wavelengths in pure Saharan dust during SAMUM 2006, Tellus B, 61, 16579, doi:10.1111/j.16000889.2008.00396.x, 2009.

Gaudichet, A., Echalar, F., Chatenet, B., Quisefit, J. P., Malingre, G., Cachier, H., Buat-Menard, P., Artaxo, P., and Maenhaut, W.: Trace elements in tropical African savanna biomass burning aerosols, J. Atmos. Chem., 22, 19-39, 1995.

Giglio, L., Descloitres, J., Justice, C. O., and Kaufman, Y. J.: An enhanced contextual fire detection algorithm for MODIS, Remote Sens. Environ., 87, 273-282, 2003.

Groß, S., Tesche, M., Freudenthaler, V., Toledano, C., Wiegner, M., Ansmann, A., Althausen, D., and Seefeldner, M.: Characterization of Saharan dust, marine aerosols and mixtures of biomassburning aerosols and dust by means of multi-wavelength depolarization and Raman lidar measurements during SAMUM 2, Tellus B, 63, 70624, doi:10.1111/j.1600-0889.2011.00556.x, 2011.

Groß, S., Esselborn, M., Weinzierl, B., Wirth, M., Fix, A., and Petzold, A.: Aerosol classification by airborne high spectral resolution lidar observations, Atmos. Chem. Phys., 13, 2487-2505, doi:10.5194/acp-13-2487-2013, 2013.
Hänel, A., Baars, H., Althausen, D., Ansmann, A., Engelmann, R., and Sun, J. Y.: One-year aerosol profiling with EUCAARI Raman lidar at Shangdianzi GAW station: Beijing plume and seasonal variations, J. Geophys. Res., 117, D13201, doi:10.1029/2012JD017577, 2012.

Holben, B. N., Eck, T. F., Slutsker, I., Tanré, D., Buis, J. P., Setzer, A., Vermote, E., Reagan, J. A., Kaufman, Y. J., Nakajima, T., Lavenu, F., Jankowiak, I., and Smirnov, A.: AERONET - a federated instrument network and data archive for aerosol characterization, Remote Sens. Environ., 66, 1-16, 1998.

Maenhaut, W., Salma, I., Cafmeyer, J., Annegarn, H. J., and Andreae, M. O.: Regional atmospheric aerosol composition and sources in the eastern Transvaal, South Africa, and impact of biomass burning, J. Geophys. Res., 101, 23631-23650, doi:10.1029/95JD02930, 1996.

Mamouri, R. E. and Ansmann, A.: Fine and coarse dust separation with polarization lidar, Atmos. Meas. Tech., 7, 3717-3735, doi:10.5194/amtd-7-3717-2014, 2014.

Mamouri, R. E., Ansmann, A., Nisantzi, A., Kokkalis, P., Schwarz, A., and Hadjimitsis, D.: Low Arabian dust extinctionto-backscatter ratio, Geophys. Res. Lett., 40, 4762-4766, doi:10.1002/grl.50898, 2013.

Markham, B. L., Schafer, J. S., Holben, B. N., and Halthore, R. N.: Atmospheric aerosol and water vapor characteristics over north central Canada during BOREAS, J. Geophys. Res., 102, 2973729745, doi:10.1029/97JD00241, 1997.

Mattis, I., Ansmann, A., Wandinger, U., and Müller, D.: Unexpectedly high aerosol load in the free troposphere over central Europe in spring/summer 2003, Geophys. Res. Lett., 30, 2178, doi:10.1029/2003GL018442, 2003.

Mattis, I., Müller, D., Ansmann, A., Wandinger, U., Preißler, J., Seifert, P., and Tesche, M.: Ten years of multiwavelength Raman lidar observations of free-tropopsheric aerosol layers over central Europe: geometrical properties and annual cycle, J. Geophys. Res., 113, D20202, doi:10.1029/2007JD009636, 2008.

McCluskey, C. S., DeMott, P. J., Prenni, A. J., Levin, E. J. T., McMeeking, G. R., Sullivan, A. P., Hill, T. C. J., Nakao, S., Carrico, C. M., and Kreidenweis, S. M.: Characteristics of atmospheric ice nucleating particles associated with biomass burning in the US: Prescribed burns and wildfires, J. Geophys. Res., 119, 10458-10470, doi:10.1002/2014JD021980, 2014.

Müller, D., Mattis, I., Wandinger, U., Ansmann, A., Althausen, A., and Stohl, A.: Raman lidar observations of aged Siberian and Canadian forest fire smoke in the free troposphere over Germany in 2003: microphysical particle characterization, J. Geophys. Res., 110, D17201, doi:10.1029/2004JD005756, 2005.

Müller, D., Mattis, I., Ansmann, A., Wandinger, U., Ritter, C., and Kaiser, D.: Multiwavelength Raman lidar observations of particle growth during long-range transport of forest-fire smoke in the free troposphere, Geophys. Res. Lett., 34, L05803, doi:10.1029/2006GL027936, 2007.

Murayama, T., Müller, D., Wada, K., Shimizu, A., Sekiguchi, M., and Tsukamoto, T.: Characterization of Asian dust and Siberian smoke with multiwavelength Raman lidar over Tokyo, Japan in spring 2003, Geophys. Res. Lett., 31, L23103, doi:10.1029/2004GL021105, 2004.

O’Neill, N. T., Eck, T. F., Holben, B. N., Smirnov, A., Royer, A., and $\mathrm{Li}, \mathrm{Z}$.: Optical properties of boreal forest fire smoke drived 
from Sun photometry, J. Geophys. Res., 107, AAC 6-1-AAC 619, doi:10.1029/2001JD000877, 2002.

O’Neill, N. T., Eck, T. F., Smirnov, A., Holben, B. N., and Thulasiraman, S.: Spectral discrimination of coarse and fine mode optical depth, J. Geophys. Res., 108, 4559, doi:10.1029/2002JD002975, 2003.

Palmer, T. Y.: Large fire winds, gases and smoke, Atmos. Environ., 15, 2079-2090, 1981.

Pappalardo, G., Amodeo, A., Apituley, A., Comeron, A., Freudenthaler, V., Linné, H., Ansmann, A., Bösenberg, J., D’Amico, G., Mattis, I., Mona, L., Wandinger, U., Amiridis, V., AladosArboledas, L., Nicolae, D., and Wiegner, M.: EARLINET: towards an advanced sustainable European aerosol lidar network, Atmos. Meas. Tech., 7, 2389-2409, doi:10.5194/amtd-7-23892014, 2014.

Petzold, A., Weinzierl, B., Huntrieser, H., Stohl, A., Real, E., Cozic, J., Fiebig, M., Hendricks, J., Lauer, A., Law, K., Roiger, A., Schlager, H., and Weingartner, E.: Perturbation of the European free troposphere aerosol by North American forest fire plumes during the ICARTT-ITOP experiment in summer 2004, Atmos. Chem. Phys., 7, 5105-5127, doi:10.5194/acp-7-51052007, 2007.
Pratt, K. A., Murphy, S. M., Subramanian, R., DeMott, P. J., Kok, G. L., Campos, T., Rogers, D. C., Prenni, A. J., Heymsfield, A. J., Seinfeld, J. H., and Prather, K. A.: Flight-based chemical characterization of biomass burning aerosols within two prescribed burn smoke plumes, Atmos. Chem. Phys., 11, 1254912565, doi:10.5194/acp-11-12549-2011, 2011.

Sakai, T., Nagai, T., Zaizen, Y., and Mano, Y.: Backscattering linear depolarization ratio measurements of mineral, sea-salt, and ammonium sulfate particles simulated in a laboratory chamber, Appl. Optics, 49, 4441-4449, 2010.

Tesche, M., Ansmann, A., Müller, D., Althausen, D., Engelmann, R., Freudenthaler, V., and Groß, S.: Vertically resolved separation of dust and smoke over Cape Verde using multiwavelength Raman and polarization lidars during Saharan Mineral Dust Experiment 2008, J. Geophys. Res., 114, D13202, doi:10.1029/2009JD011862, 2009.

Tesche, M., Müller, D., Groß, S., Ansmann, A., Althausen, D., Freudenthaler, V., Weinzierl, B., Veira, A., and Petzold, A.: Optical and microphysical properties of smoke over Cape Verde inferred from multiwavelength lidar measurements, Tellus B, 63, 677-694, doi:10.1111/j.1600-0889.2011.00549.x, 2011. 